\title{
The Role of Emotions in Leadership
}

\author{
Halimah M. Yusof ${ }^{1}$, Hamdan A. Kadir ${ }^{1} \&$ Mastura Mahfar ${ }^{1}$ \\ ${ }^{1}$ Faculty of Management, Universiti Teknologi Malaysia, UTM Skudai, Johor, Malaysia \\ Correspondence: Halimah M. Yusof, Faculty of Management, Universiti Teknologi Malaysia, UTM Skudai, \\ 81310 Johor, Malaysia. E-mail: halimahmy@gmail.com
}

Received: November 19, $2013 \quad$ Accepted: March 3, $2014 \quad$ Online Published: April 29, 2014
doi:10.5539/ass.v10n10p41
URL: http://dx.doi.org/10.5539/ass.v10n10p41

\begin{abstract}
Emotions play an important role in the field of leadership. The intelligent use of emotions may be beneficial for leaders in achieving success. In fact, good use of emotions has been seen as a prerequisite for effective leadership. Leaders with high emotional competencies are perceived as more efficient by their followers. Besides, the use of emotional intelligence (EI) was found to be linked with transformational leadership. Furthermore, leaders' EI was found to be affecting followers' and organizational outcomes. Thus, we provide a selective review on the relationship between emotions and leadership. Our findings showed that EI is essential for successful leadership as it provides many benefits to leaders. With the use of EI, leaders could manage the team intelligently, handle difficult situations properly and reduce their stress effectively. Hence, we identified that it is necessary for researchers to further study the links between EI and leadership to gain the most benefits from it. We conclude with a discussion on the theoretical and practical implication, as well as some recommendation for future research with the promising use of EI in leadership development.
\end{abstract}

Keywords: emotions, leaders, effective leadership

\section{Introduction}

The intelligent use of emotions has long been associated with effective leadership. Defined as the ability to control ones' emotions and understanding others' emotions, emotional intelligence (EI) is undeniably an important factor for leaders to build good rapport with their subordinates (Weisinger, 1998). In fact, a growing body of research literatures supported the essentiality of EI in the workplace, especially among leaders (Goleman, Boyatzis, \& McKee, 2002). For instance, studies have shown that emotional intelligence (EI) could positively influence individual's leadership skills (e.g., Hong, Catano, \& Liao, 2011; Hur, van den Berg, \& Wilderom, 2011). With EI, leaders would be able to handle stressful situation and conflicts by intelligently manage the emotion of self and others. Hence, EI was often used as a measurement of leaders' effectiveness (e.g., Kerr, Garvin, Heaton, \& Boyle, 2005; Madera \& Smith, 2009; Thiel, Connelly, \& Griffith, 2012). Indeed, individual with high EI is perceived as a better leader compared to those with lower EI (Thiel et al., 2012). Hence, the researcher believed that the link between EI and leadership should be further studied to gain better understanding and benefit from it. This review discusses the link between EI and leadership with the focus on the importance of EI on leadership.

\subsection{The Importance of Studying the Link between Emotions and Leadership}

Studies have shown useful link between EI and leaders in the workplace. For instance, the integration of the cognitive and emotional aspect would resulted in better decision making as leaders approach the problems more holistically (Rajah, Song, \& Arvey, 2011). As countries change from a machine based industrial to a service based industry, EI has been seen as an essential factor in the workforces and considered as a critical aspect of human resources (Assanova \& McGuire, 2009). In fact, Goleman (1998a) emphasizes that in the present changing environment, the use of EI by leaders will lead them to achieve greater success. EI of the leaders will influence the accomplishment of the organization as it could create a better work environment through the proper use of emotions (Goleman, 1998a). Furthermore, EI was found to an important factor in creating a successful work environment (Cross \& Travaglione, 2003). It is found that leaders' emotions is positively linked to good leadership attributes such as leaders' effectiveness, positive contagion effect, less burnout and good performance outcomes (Rajah et al., 2011). This idea has attracted many people in the business world. However, through the literature reviews, it is found that there have been many debates on the importance of good use of emotion on 
leaders. A thorough literature review would be beneficial to clear some lights on this matter. Thus, this literature review is done to highlight the links between emotions and leadership. With the understanding on the importance of emotional competency on leaders, further attention could be given on the emotional aspects of leadership in future studies.

\section{Method}

In conducting this review, research reviews were done on articles between 2000-2012 that are related to the studies on Emotion and Leadership. Reviews were conducted based on available peer-reviewed journals and books chapters. The reviews focus on highlighting the theoretical links between leadership and emotion. Searches were done on Science Direct and Scopus as well as internet searches for other articles and online books. Keywords used for these searches were emotions and leadership. For this review, special focus will be on the link between EI, transformational leadership, and leadership effectiveness.

\section{Theoretical Background}

\subsection{Emotional Intelligence}

The recent working definition of EI is 'the ability to carry out accurate reasoning about emotions and the ability to use emotions and emotional knowledge to enhance thought' (Mayer, Roberts, \& Barsade, 2008, p. 511). The intelligent use of emotions is essential in our life as it has many benefits. For instance, EI is believed to be the basis for many personal qualities such as self-esteemed, self-motivation, self-determination, and self-competence (Cherniss \& Adler, 2000). To provide more understanding on EI, the theoretical background and its models are discussed below.

\subsubsection{Theoretical Background}

The theory of emotional intelligence has started in 1920 when Thorndike mentioned about the probability of other types of intelligence in the Harper's Magazine (Matthews, Zeidner, \& Roberts, 2002). Later, in 1983, Howard Gardner introduced the 'multiple intelligences' theory. In his theory, Gardner (1983) proposed seven intelligences, among them are interpersonal and intrapersonal intelligence. Many years later, in his book titled "Multiple Intelligence", Gardner define interpersonal intelligences as the capability to recognize the differences between individuals, especially the differences in the emotions, characteristics, motivations, and life purposes of each individual (Gardner, 1993). On the other hand, Peter Salovey and John Mayer (1990) clearly provide the definition of EI as the ability to monitor emotions in self and others, discriminate emotions and use emotions to facilitate thought and actions. They strongly believe that there are individuals who have a good understanding of emotion and could handle problems concerning emotions better than others do. Since then, Mayer and Salovey have written multiple academic articles regarding EI and managed to develop inventories that could measure the EI of individuals. Despite all the studies and contributions made by Mayer and Salovey, it was Goleman who had publicized the theory of EI through his book "Emotional Intelligence: Why it can matter more than IQ" (Goleman, 1996). The publication became a best seller and since then, the term EI has been extensively used.

Although some researcher argued on the reliability of the EI theory (e.g., Harmon, 2000; Matthews, Roberts, \& Zeidner, 2004; Murphy \& Sideman, 2006), there are many rationales to the quick and extensive dispersal of the term EI in the business industry. Many professionals have recognized the significance and magnitude of emotional competencies in their workplace success (Fernandez-Berrocal \& Extremera, 2006). Furthermore, many researchers support and validate the importance of EI not only in individual's success, but also to the success of the working environment (e.g., Cherniss \& Goleman, 2001; Dulewicz \& Higgs, 2010; Hein, 1996; Henry, 2011; Howells, 2007; Weinberger, 2009). Therefore, EI has turn into an acceptable and appropriate theory that promises various benefits (Caruso \& Salovey, 2004).

\subsubsection{EI Model}

There have been many EI models proposed by researchers over the years. According to Mayer, Salovey, and Caruso (2000) in their book chapter titled: 'Models of Emotional Intelligence', the theoretical models that are recognized by the scientific researchers are the Ability Model of EI (Mayer \& Salovey, 1997), Emotional-Social Intelligence Model (Bar-On, 1997), and Emotional Competencies Model (Goleman, 1995). These three models can be classified into two categories. First, is the ability-model that associates both emotions and intelligence as talents (e.g., Mayer \& Salovey, 1997). Second, is the mixed-models concept that includes mental capabilities, dispositions, and characteristics as EI (e.g., Bar-On, 1997; Goleman, 1995). The primary differences between these three concepts are that Mayer and Salovey's idea emphasizes solely on the interaction between the emotional competencies and cognitive abilities, while Goleman's and Bar-On's theories consist of emotion, cognition and motivation that includes some human characteristics such as faith, positivism and selflessness. 
Mayer and Salovey's ability model is said to be the most mentioned and be acquainted with by many scientific researchers compared to any other models (Geher, 2004; Matthews et al., 2002). The Mayer and Salovey's ability model proposed four-branch emotional-abilities that describe individuals' EI. These abilities are in a chain of command, in which, every level integrates with one another and constructed the competence of the earlier level. The EI's building blocks proposed by Mayer and Salovey (1997) are: (a) Perception and appraisal of own and others' emotion, which is the capacity to observe, assess, and convey their emotion precisely; (b) Ability to assimilate emotions, which is the capacity to precipitate emotions accordingly; (c) Ability to understand and reason the emotions, which is the capacity to comprehend feelings, and understand information originating from the feelings; and (d) Ability to manage and regulate one's emotion, which is the capacity to control feelings to develop one's emotion and intellect. This ability theory is regarded as a valid concept by many of the reviewers of the EI theory, as it is believed to contribute significantly to a person personality even from diverse backgrounds (Geher, 2004; Joseph \& Newman, 2010; Matthews et al., 2002).

\subsection{Leadership Theory}

Leadership has been the topic of interest for many years. Many of the earliest researches on leadership viewed leader as a tactician, not as an inspirational figures, however, recently, researchers have turn their attention to leader's psychological and charismatic attributes (Arnold et al., 2005). Leaders were seen as someone who could have an influence on their followers and contribute to the success of the organization by channelling teams' effort to achieve organizational goals. Supporting this, Yulk and Van Fleet defines leadership as "a process that influencing the task objectives and strategies of an organization, influencing people in the organization to implement the strategies and objectives, and influencing the culture of the organization" (1992, p. 149). Since the realisation that leadership is more than the use of cognitive and technical skills, many ideas have been thrown on the leadership theory and leaders' attributes. For instance, leadership is said to include the ability to influence others' behaviour, possess variety of skills such as strong analytical conceptual skills to influence task's objectives and strategy, and interpersonal and persuasive skills to influence people to implement strategies and objectives (Jex \& Britt, 2008). Furthermore, leadership is considered as a process and not the result. Leaders have series of responsibility to ensure the team functioned effectively (Jex \& Britt, 2008). For instance, leaders need to establish the team objectives, develop strategies to achieve the objective, implement and maintain the strategies and enforce the organization culture to the team. Thus, leaders become important agent of change in organizations since they are in the best position to facilitate cultural changes.

The ways leaders function and behave in the workplace determine their leadership style. Few leadership styles were identified; among them are the transformational and transactional leadership. The transformational leadership style involves creating enthusiasm between co-workers, encouraging new perspective in the job, making the objectives of the company is known to the employees, helping to increase employees' capability and instilling the motivation of team members (Bass \& Avolio, 1994). On the contrary, the transactional leadership style involves rewarding or disciplining employees based on their work output. Those with transactional leadership style put priority on the job's standard, tasks' completion and workers' conformity. They manage their employees by rewarding and disciplining to achieve the workers' highest efficiency level (Bass \& Avolio, 1994).

Studies have been done to investigate the impact of the transformational and transactional leaders in the workplace. Findings showed that transformational leaders were perceived as more efficient by the employees (Dasborough, Ashkanasy, Tee, \& Tse, 2009; Hater \& Bass, 1988), showed greater team achievements (Hur et al., 2011; Keller, 1995), and gained better cooperation from the employees (Dulewicz \& Higgs, 2010; Seltzer \& Bass, 1990) compared to the transactional leaders. Furthermore, transformational leaders were found to demonstrate good use of emotional skills (Furtner, Rauthmann, \& Sachse, 2010). The transformational leaders' main facets were outlined as; idealized influence, inspirational motivation, intellectual inspiration, and personal thoughtfulness (Bass \& Avolio, 1994). Thus, leaders that show the transformational leadership style are more preferred by organizations as these leaders could provide a positive and conducive working environment, and lead the team to success.

\subsubsection{Role of Leaders in the Workplace}

Leaders play an important role in the workplace. Leaders are the link between the employees and the higher-level authorities in the organization (Likert, 1967). Therefore, leaders should provide strategic direction to their teams towards achieving the organization's goal (Bass, 1998). For instance, leaders could guide employees' behaviours in directions that are beneficial for the organization by exhibiting appropriate leadership style according to situations. Equally important, leaders should provide clear understanding on organization's 
goals and policies to the team members. Furthermore, leaders could motivate and coach their employees to achieve success (Jex \& Britt, 2008). The need for constant encouragement and assistance from leaders are essential for employees especially in solving their work problem. Thus, leaders should become the enforcement agent and push their team to their best. To do so, leaders should be responsible in obtaining resources for the team so that the team's tasks could be completed accordingly (Jex \& Britt, 2008).

Good leadership skills are crucial in the workplace and play important function in shaping the success of an organization. However, to be successful, leaders requires some emotional capabilities. Hence, it is suggested that the social and emotional competencies should be instilled to achieve the most effective leadership approach, which is the transformational leadership style (Furtner et al., 2010; Matear, 2009). In fact, emotional capabilities have been considered as important aspect in motivating workers and in establishing rapport in team members. Dulewicz and Higgs (2010) purported that EI is important in a leader and would increase the effectiveness of a leader. Thus, it could be concluded that emotional abilities are useful in increasing leader's effectiveness (Howells, 2007). Next, is the discussion on the links between leadership effectiveness and EI.

\section{Discussion on Emotions and Leadership}

Over the years, researchers have realized that IQ is not the only important factor in a good leader. The need to use emotions intelligently is essential for leaders especially when dealing with people (Goleman et al., 2002). Hence, emotional intelligent has been linked to leadership, in fact, leadership is among the most often concept connected with EI (e.g., Badea \& Pana, 2010; Dulewicz \& Higgs, 2010; Henry, 2011; Hong et al., 2011; Nadler, 2011). As seen in previous discussion, the early approach to leadership described leader's behaviour to be a static set of attributes. Earlier leadership theorists believed that to be effective, leaders need to perform certain behaviours and do so in whatever the situation are (Arnold et al., 2005). However, in the real world, we need leaders that could adapt to various situations. This requires some flexibility from the leaders. Fiedler (1967) realized this shortcoming and proposed a contingency theory of leadership. His theory proposed that the success of a leader depends on the interaction between the condition of the situation and characteristics of the leader. He proposed that different situation demand different behaviours from the leaders. His theory, however, received many critics from other researchers who insist leadership requires some static attributes (Arnold et al., 2005).

Much later on, Fiedler (1995) introduced a new cognitive-resources theory proposing that in difficult situations, leaders need to use their experience rather than their intelligence to handle the situation. He believed that problems could be solved better by using emotional capability, in which, leaders could use their experience as a guide to handle various situations that occurs in the workplace. Fiedler theory is in line with Vroom and Yetton (1973) that proposed a contingency theory on leader's decision-making. Vroom and Yetton contended that flexibility in making decision is essential in leadership. Then, in 1988, Vroom and Jago extended their theory and suggested that leaders should be able to adjust their approach based on the situation. They emphasize that the nature of a situation is determined by many factors, which include the pressure of time, clarity of the decision's parameters and attitudes of the subordinates. Thus, all these factors should be considered in making the best decision and it requires some level of emotion-related judgment skills by the leaders. With the use of emotional intelligence, leaders would be able to provide better solutions according to the situations and solve problems wisely.

Many years later, the intelligent use of emotion is seen as a requirement in good leadership by researchers (e.g., Dulewicz \& Higgs, 2010; Gooty, Connelly, Griffith, \& Gupta, 2010; Hong et al., 2011; Hur et al., 2011; Nadler, 2011). Researchers began to focus on the links between EI and leadership. For instance, Goleman (2001) emphasized that the accomplishment of an organization depends on the EI of the leaders. He investigated the competency required for efficient functioning in the workplace and found that two-thirds of the abilities necessary for good performance are those that involve emotions. For the leadership position, the percentage increased to almost ninety-percent. Thus, he claimed that good leaders should have the ability to control their team by spreading positive emotions and providing a comfortable working environment. Good leadership involves the capability of not only controlling their own emotional state, but also the capability of understanding followers' emotions and overcoming difficulties. These attributes will help leaders gain their followers' confidence and trust in them.

Leaders' effectiveness is of determined by their emotional competencies. Goleman (1998a) proposed that leaders with high EI would be able to communicate and develop interest to achieve the organization goals, be the guide when required, manage others to perform well, and be an inspiration to others. In fact, the Emotional and Social Competence Inventory (ESCI) created by both Goleman and Boyatzis has been used to measures the effectiveness of leaders, and is considered as an instrument in evaluation and development of good leaders 
(Howells, 2007). Aside from Goleman, Bar-On (1997) supports that effective leadership requires EI. Hence, the Bar-On Emotional Quotient Inventory (EQ-i) is often used to measures the correlation between EI and the effectiveness of a leader (Bar-On, 2004). The use of EI measurement as an indication of leadership effectiveness showed that there is a link between these two. Literature review done by Rajah et al. (2011) on peer-reviewed journals from 2000 to 2010 supported the fact that EI is important for leaders. They found that leaders with high EI would be able to support and motivate their employees. Thus, would yield positive outcomes in the workplace. Therefore, they concluded that EI is positively linked to good leadership attributes.

In line with the above researches, many other researchers have done the studies to evaluate the link between EI and leaders. In fact, some proofs on the links between EI and transformational leadership were found. An example of a study that has detected the links between the transformational leaders and EI was done by Mandell and Pherwani (2003). In this study, thirty-two managers were used to evaluate the links between transformational leaders and their EI level. The Bar-On EQ- $i$ was used as the instrument to measure leaders' EI. Their findings showed that the total EI of the leaders was highly correlated with transformational leadership style with the results of $R=0.50$. Similar study conducted by L. Gardner and Stough (2002) on 110 high level manager proved the existence of some links between EI and transformational leaders too. The Swinburne University Emotional Intelligence Test was used as their EI measurement inventory and showed that EI and transformational leadership were highly correlated with the results of $R=0.675$. This could be explained by the fact that transformational leadership involves understanding, inspiring, challenging and motivating followers. All this facets requires the use of EI by the leaders. Thus, the links between EI and transformational leadership is expected.

Emotions could be seen through facial expression, body gestures and voice intonation. Consequently, leaders' emotion was found to affect followers' outcomes. A comprehensive review done by Gooty et al. (2010) showed that EI does have an effect on leaders and their employees. Their review on 78 peer-reviewed journals and 21 books chapters from 1990 to 2007 proved that leaders' emotional outlook do have an effect on their employees. For instance, they found that leaders' positive outlook could result in positive team outcomes, while leaders' negative outlook might hinder the team effectiveness (Gooty et al., 2010). As normal human being, followers will be affected by the way their leaders showed their emotions. For instance, leaders that often exhibit negative facial expressions will cause a hostile environment and this may affect the followers' moral and enthusiasm. On the contrary, the use of positive facial expression and body language might help to make followers feel at ease and thus, are more motivated in the workplace. This shows that, not only the leaders should manage their emotions internally, their emotional outlook plays an important too.

Indeed, studies shown that leaders with high EI were perceived better than those with lower EI. For instance, study by Thiel et al. (2012) shown that leaders who exhibit anger and pessimism in stressful situation was rated as less effective by their followers. This finding showed that followers believe that leaders with the ability to control their emotions is an effective leader and is well respected. Another study by Connelly and Ruark (2010) supports this notion, in which their findings showed that leaders who shown positive emotional display such as pride, challenge, and responsibility were perceived as more effective leaders. Similarly, study done by Byron (2007) revealed that leaders with higher ability on perceiving emotions gain higher ratings on their leadership effectiveness from the followers. These findings suggest that leaders are perceived as more effective if their have higher emotional competencies. Followers believe in leaders that showed positive emotional attributes as more reliable than those who showed negative emotions. Indeed, it is the tendency of human being to perceive the ability to control one's emotion is a strong human characteristic, while those who lacks of emotional control is considered as 'weak'.

\subsection{Theoretical and Practical Implication}

There are several implications for studying emotional aspects of leaders. First, leaders can benefit from studies that shown the importance of EI on them. Through EI, leaders could increase their effectiveness in handling problematic employees, managing difficult tasks in the workplace. Hence, the emotional aspects in leaders are as important as their cognitive aspects. The equal use of emotional and cognitive skills would improve leaders' effectiveness in the workplace and increase the chance for the leader to be successful. Secondly, the use of emotions benefit leaders as an emotionally intelligence leaders could recognize their followers' needs and thus, establish good rapports with them (Gooty et al., 2010). Social interaction between leaders and followers are important in the workplace. By establishing good leader-follower relationship, leaders would be able to provide instructions and guidance to their team to achieve organization goals. Leaders could establish this bonding through proper use of the emotions. Thus, good control of emotion would result in better leadership perception and thus, would increase the follower's trust in the leaders (Gardner, Fischer, \& Hunt, 2009). Thirdly, by 
understanding ways to manage emotions, leaders would be able to overcome the stressful situations they face in their working environment. It could be a tool for them to manage stress and thus, increasing their productivity and efficiency in the workplace. This would create a conducive working environment in the workplace. Finally, the study on the effective use of emotions on leaders could contribute to the theoretical understanding on the relationship between emotions and leadership. More insight could be gathered on the benefits of emotions in leaders through these studies. Hence, this would benefits the field of leadership study.

\subsection{Recommendation for Future Research}

As we have seen the importance of EI on leaders, special attention should be given to the development of leaders' emotional aspect. Hence, good emotional-related training program should be design and studied. Developing leaders' EI might be a good start to increase the leaders' emotional abilities. More research should be conducted to formulate a good EI training program for leaders' development. This is to encourage the effective use of emotions by leaders and for them fully utilize the benefits of using emotions in their workplace. Additionally, more studies should be done to evaluate the connection between emotion, leadership, performance, and other variables to gather more knowledge for better understanding on the effects of emotion on leaders. Leadership scholars are suggested to study more of these promising possibilities in their future research.

\section{Conclusion}

In conclusion, it is undeniable that EI is a significant factor in effective leadership. Leaders could definitely benefit from the use of emotional intelligence as the ability to perceive emotions, assimilate of emotions, understand emotions and manage emotions are essential skills for leaders to manage their employees and control the workplace situation In fact, leaders that used more holistic skills are more likely to create a greater workplace condition (Pinos, Twigg, Parayitam, \& Olson, 2006). Furthermore, highly intelligence leaders are perceived better and produced positive outcomes to the followers. With emotionally intelligence leaders, workers will feel comfortable and enthusiastic at the workplace, gain the motivation to perform and will contribute their best to achieve the organizational goals. Thus, the role of emotions on leadership should be further studied and understood to get the most benefit out of it.

\section{References}

Arnold, J., Silvester, J., Patterson, F., Robertson, I., Cooper, C., \& Burnes, B. (2005). Work psychology: Understanding human behaviour in the workplace. Pearson Education.

Assanova, M., \& McGuire, M. (2009). Applicability analysis of the emotional intelligence theory. Indiana University.

Badea, L., \& Pana, N. A. (2010). The role of empathy in developing the leader's emotional intelligence. Theoretical \& Applied Economics, 17(2), 69-78.

Bar-On, R. (1997). The Bar-On emotional quotation inventory (EQ-I): A test of emotional intelligence. Toronto, Canada: Multi-Health Systems.

Bar-On, R. (Ed.). (2004). The Bar-On emotional quotient inventory (EQ-i): Rationale, description and psychometric properties. Hauppauge, N.Y: Nova Science Publishers.

Bass, B. M. (1998). Transformational leadership: Industrial, military, and educational impact. Mahwah, NJ: Erlbaum.

Bass, B. M., \& Avolio, B. J. (1994). Improving organizational effectiveness through transformational leadership. Thousand Oaks, CA: Sage.

Byron, K. (2007). Male and female managers' ability to read emotions: Relationships with supervisor's performance ratings and subordinates' satisfaction ratings. Journal of Occupational and Organizational Psychology, 80(4), 713-733. http://dx.doi.org/10.1348/096317907X174349

Caruso, D. R., \& Salovey, P. (2004). The emotionally intelligence manager: How to develop and use the four key emotional skills of leadership. CA: John Wiley \& Sons.

Cherniss, C., \& Adler, M. (2000). Promoting emotional intelligence in organization: Make training in emotional intelligence effective. American Society for Training \& Development.

Cherniss, C., \& Goleman, D. (2001). The emotionally intelligence workplace: How to measure, and improve emotional intelligence in individuals, groups and organizations. San Francisco: Jossey Bass.

Connelly, S., \& Ruark, G. (2010). Leadership style and activating potential moderators of the relationships among leader emotional displays and outcomes. The Leadership Quarterly, 21(5), 745-764. 
http://dx.doi.org/10.1016/j.leaqua.2010.07.005

Cross, B., \& Travaglione, A. (2003). The untold story: Is the entrepreneur of the 21 st century defined by emotional intelligence? International Journal of Organizational Analysis, 11(3), 221-228. http://dx.doi.org/10.1108/eb028973

Dasborough, M. T., Ashkanasy, N. M., Tee, E. Y. J., \& Tse, H. H. M. (2009). What goes around comes around: How meso-level negative emotional contagion can ultimately determine organizational attitudes toward leaders. The Leadership Quarterly, 20(4), 571-585. http://dx.doi.org/10.1016/j.leaqua.2009.04.009

Dulewicz, V., \& Higgs, M. (2010). Leadership at the top: The need for emotional intelligence in organizations. The International Journal of Organizational Analysis, 11(3), 193-210. http://dx.doi.org/10.1108/eb028971

Fernandez-Berrocal, P., \& Extremera, N. (2006). Emotional intelligence: A theoretical and empirical review of its first 15 years of history. Psicothema, 18, 7-12.

Fiedler, F. E. (1967). A theory of leadership effectiveness. New York: McGraw-Hill.

Fiedler, F. E. (1995). Cognitive resources and leadership performance. Applied Psychology: An International Review, 44, 5-28. http://dx.doi.org/10.1111/j.1464-0597.1995.tb01378.x

Furtner, M. R., Rauthmann, J. F., \& Sachse, P. (2010). The socioemotionally intelligent self-leader: Examining relations between self-leadership and socioemotional intelligence. Social Behavior \& Personality: An International Journal, 38(9), 1191-1196.

Gardner, H. (1983). Frames of mind. New York: Basic Books.

Gardner, H. (1993). Multiple Intelligences: The theory in practice. New York: Basic Books.

Gardner, L., \& Stough, C. (2002). Examining the relationship between leadership and emotional intelligence in senior level managers. Leadership \& Organization Development Journal, 23(2), 68-78. http://dx.doi.org/10.1108/01437730210419198

Gardner, W. L., Fischer, D., \& Hunt, J. G. (2009). Emotional labor and leadership: A threat to authenticity? The Leadership Quarterly, 20(3), 466-482. http://dx.doi.org/10.1016/j.leaqua.2009.03.011

Geher, G. (2004). Measuring emotional intelligence: Common ground and controversy. New York: Nova Science.

Goleman, D. (1995). Emotional Intelligence. New York: Bantam Books.

Goleman, D. (1996). Emotional intelligence: Why it can matter more than IQ. New York: Bantam Books.

Goleman, D. (1998a). The emotional intelligence of leaders. Leader to Leader, (10), 20-26. http://dx.doi.org/10.1002/lt1.40619981008

Goleman, D. (1998b). Working with emotional intelligence. New York: Bantam Books.

Goleman, D. (Ed.). (2001). Emotional intelligence: Perspectives on theory of performance. San Francisco: Jossey-Bass.

Goleman, D., Boyatzis, R. E., \& McKee, A. (2002). Primal leadership: Realizing the power of emotional intelligence. Boston: Harvard Business School Press.

Gooty, J., Connelly, S., Griffith, J., \& Gupta, A. (2010). Leadership, affect and emotions: A state of the science review. The Leadership Quarterly, 21(6), 979-1004. http://dx.doi.org/10.1016/j.leaqua.2010.10.005

Harmon, P. (2000). Emotional intelligence: Another management fad, or skill of leverage? Center for Quality of Management Journal, 9(1), 43-51.

Hater, J. J., \& Bass, B. M. (1988). Superior's evaluations and subordinates' perceptions of transformational and transactional leadership. Journal of Applied Psychology, 73(4), 695-702. http://dx.doi.org/10.1037/0021-9010.73.4.695

Hein, S. (1996). EQ for everybody: A practical guide to emotional intelligence. Aristotle Press.

Henry, S. (2011). EQ and leadership in Asia: Using emotional intelligence to lead and inspire your people. San Francisco, CA: John Wiley \& Sons.

Hong, Y., Catano, V. M., \& Liao, H. (2011). Leader emergence: The role of emotional intelligence and motivation to lead. Leadership \& Organization Development Journal, 32(4), 320-343. http://dx.doi.org/10.1108/01437731111134625 
Howells, G. N. (2007). Emotional Intelligence and Leadership. Department of Psychology, University of the Pacific. California.

Hur, Y., van den Berg, P. T., \& Wilderom, C. P. M. (2011). Transformational leadership as a mediator between emotional intelligence and team outcomes. The Leadership Quarterly, 22(4), 591-603. http://dx.doi.org/10.1016/j.leaqua.2011.05.002

Jex, S. M., \& Britt, T. W. (2008). Organizational Psychology: A scientist-practitioner approach (2nd ed.). New Jersey: John Wiley \& Sons.

Joseph, D. L., \& Newman, D. A. (2010). Emotional intelligence: An integrative meta-analysis and cascading model. Journal of Applied Psychology, 95(1), 54-78. http://dx.doi.org/10.1037/a0017286

Keller, R. T. (1995). Transformational leaders make a difference. Journal of Research and Technology Management, 38, 41-44.

Kerr, R., Garvin, J., Heaton, N., \& Boyle, E. (2005). Emotional intelligence and leadership effectiveness.

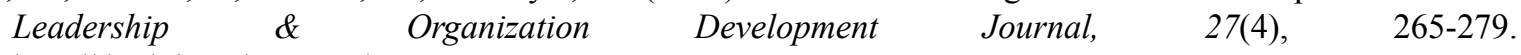
http://dx.doi.org/10.1108/01437730610666028

Likert, R. (1967). The Human Organization. New York: McGraw-Hill.

Madera, J. M., \& Smith, D. B. (2009). The effects of leader negative emotions on evaluations of leadership in a crisis situation: The role of anger and sadness. The Leadership Quarterly, 20(2), 103-114. http://dx.doi.org/10.1016/j.leaqua.2009.01.007

Mandell, B., \& Pherwani, S. (2003). Relationship between emotional intelligence and transformational leadership style: A gender comparison. Journal of Business and Psychology, 17(3), 387-404. $\mathrm{http}: / / \mathrm{dx}$. doi.org/10.1023/A:1022816409059

Matear, D. (2009). An examination of cognitive, cultural, and emotional intelligences, and motivation in the development of global transformational leadership skills. (Ph.D. 3387673), Capella University, United States-Minnesota. Retrieved from http://proquest.umi.com/pqdweb?did=1940114351\&Fmt=7\&clientId= 21690\&RQT $=309 \&$ VName $=$ PQD

Matthews, G., Roberts, R. D., \& Zeidner, M. (2004). Seven myths about emotional intelligence. Psychological Inquiry, 15(3), 179-196. http://dx.doi.org/10.1207/s15327965pli1503_01

Matthews, G., Zeidner, M., \& Roberts, R. D. (2002). Emotional intelligence: Science and myth. Cambridge, Massachusetts: MIT Press.

Mayer, J. D., \& Salovey, P. (1997). What is emotional intelligence? In P. Salovey, \& D. Sluyter (Eds.), Emotional development and emotional intelligence: Implications for educators (pp. 3-31). New York: Basic Books.

Mayer, J. D., Roberts, R. D., \& Barsade, S. G. (2008). Human abilities: Emotional intelligence. The Annual Review of Psychology, 59, 507-536. http://dx.doi.org/10.1146/annurev.psych.59.103006.093646

Mayer, J. D., Salovey, P., \& Caruso, D. R. (2000). Models of emotional intelligence. In R. Sternberg (Ed.), Handbook of Intelligence (2nd ed., pp. 396-420). New York: Cambridge University Press. http://dx.doi.org/10.1017/CBO9780511807947.019

Murphy, K. R., \& Sideman, L. (2006). The fadification of emotional intelligence. In K. R. Murphy (Ed.), $A$ critique of emotional intelligence: What are the problems and how can they be fixed? New Jersey: Lawrence Erlbaum Associates.

Nadler, R. S. (2011). Leading with emotional intelligence. New York: McGraw-Hill Companies, Inc.

Pinos, V., Twigg, N. W., Parayitam, S., \& Olson, B. J. (2006). Leadership in the 21 st Century: The effect of emotional intelligence. Academy of Strategic Management Journal, 5, 61-74.

Rajah, R., Song, Z., \& Arvey, R. D. (2011). Emotionality and leadership: Taking stock of the past decade of research. The Leadership Quarterly, 22(6), 1107-1119. http://dx.doi.org/10.1016/j.leaqua.2011.09.006

Salovey, P., \& Mayer, J. D. (1990). Emotional intelligence. Imagination, cognition and personality. Baywood Publication Co., Inc, 9, 185-211.

Seltzer, J., \& Bass, B. M. (1990). Transformational leadership: Beyond initiation and consideration. Journal of Management, 16, 693-703. http://dx.doi.org/10.1177/014920639001600403

Thiel, C. E., Connelly, S., \& Griffith, J. A. (2012). Leadership and emotion management for complex tasks: 
Different emotions, different strategies. The Leadership Quarterly, 23(3), 517-533. http://dx.doi.org/10.1016/j.leaqua.2011.12.005

Vroom, V. H., \& Jago, A. G. (1988). The new leadership: Managing participation in organizations. Englewood Cliffs, NJ: Prentice Hall.

Vroom, V. H., \& Yetton, P. W. (1973). Leadership and decision making. Pittsburgh, PA: Pittsburgh Press.

Weinberger, L. A. (2009). Emotional intelligence, leadership style, and perceived leadership effectiveness. Advances in Developing Human Resources, 11(6), 747-772. http://dx.doi.org/10.1177/1523422309360811

Weisinger, H. (1998). Emotional intelligence at work: The untapped edge for success. San Francisco: Jossey-Bass Publisher.

Yukl, G., \& Van Fleet, D. D. (1992). Theory and research on leadership in organizations. In M. D. Dunnette, \& L. M. Hough (Eds.), Handbook of Industrial and Organizational Psychology (2nd ed., Vol. 2, pp. 147-197). Palo Alto, CA: Consulting Psychologists Press.

\section{Copyrights}

Copyright for this article is retained by the author(s), with first publication rights granted to the journal.

This is an open-access article distributed under the terms and conditions of the Creative Commons Attribution license (http://creativecommons.org/licenses/by/3.0/). 